\title{
EVALUATION OF STABILITY OF POTENTIAL BETA- ADRENOLYTICS IN VARIOUS SOLUTIONS BY THIN LAYER CHROMATOGRAPHY AND BY KINETICS OF HYDROLYSIS
}

\author{
${ }^{1}$ Stankovičová, M. - ${ }^{1}$ Bezáková, Ž. - ${ }^{2}$ Mokrý, P. $-{ }^{2}$ Csöllei, J. $-{ }^{1}$ Pažitná, M. - \\ ${ }^{1}$ Liptáková, B. $-{ }^{1}$ Ševčíková, Z. - ${ }^{2}$ Dvořáková - Kotlíková, S. \\ ${ }^{1}$ Comenius University in Bratislava, Faculty of Pharmacy, \\ Department of Pharmaceutical Chemistry \\ ${ }^{2}$ University of Veterinary and Pharmaceutical Sciences Brno, \\ Faculty of Pharmacy, Institute of Chemical Drugs
}

The aim of this work is the study of stability and kinetics of hydrolysis of the chosen compounds, derivatives of 2-hydroxy-3-[2-(4-methoxyphenyl)ethylamino]propyl-4[(alkoxycarbonyl)amino]benzoates and 2-hydroxy-3-[2-(2-methoxyphenyl)ethylamino] propyl-4-[(alkoxycarbonyl)amino]benzoates with potential ultra-short beta-adrenolytic activity. The studied compounds are different in the position of the substituent on the benzene ring in the side chain as well as in the aromatic ring in position 4 with alkyl(methyl- to butyl-) carbamate. Thin layer chromatography and UV-area spectrophotometry are used in order to establish the stability of these potential pharmaceuticals. The stability studies of the compounds were examined in acidic and alkaline media, in buffers and due oxidation at room and at elevated temperature chromatographically, and $R_{f}$ values of incipient products and degradation products were detected. Kinetics of acid and base hydrolysis in various solutions at temperatures $80^{\circ} \mathrm{C}$ and $100{ }^{\circ} \mathrm{C}$ were examined through UV-area spectrophotometry. Kinetic parameters such as rate constant $k$, half-life period $t_{1 / 2}$ and usable life $t_{90}$ were determined.

Keywords: ultra short acting beta-blockers - stability study - kinetics of hydrolysis

\section{INTRODUCTION}

Ultra-short acting beta-blockers comprise a special group of beta-adrenergic receptor antagonists suitable for injection application with short biological half-life $(<30 \mathrm{~min})$ 
(Jackman et al., 2002) The fast start of the pharmacological effect and a short biological half-life of such drugs is utilised in intravascular application at sudden heart failures for elimination of the dangerous accompanying reactions as well as in the therapy of glaucoma. The ultra-short effect of antagonists of the beta-adrenergic receptor is possible to obtain by incorporation a metabolically unstable ester functional group into original aryloxyaminopropanol structure (Bodor \& Buchwald, 2000) The ester group may be placed in the lipophilic part of molecule or in the basic hydrophilic part as well as in the connecting chain of molecule. The review of ultrashort acting beta-adrenergic receptor blocking agents is published in the article (Kečkéšová, 2010).

The studied compounds are derivatives of [(arylcarbonyl)oxy]aminopropanol, with carbamate substitution on a benzene ring. The compounds are potential ultra-short acting beta-adrenergic receptor blocking agents which were prepared at the Institute of Chemical drugs of the University of Veterinary and Pharmaceutical Sciences Brno, Czech Republic (Mokrý et al., 2003, 2011). The list of studied compound is shown in Table 1.

Table 1. List of the studied compounds<smiles>COc1ccc(CCNCC(O)COC(=O)c2ccc(NC(=O)O)cc2)cc1</smiles>

$\begin{array}{cccc}\text { Compound } & \mathrm{R} & \text { Position in ring } & \mathrm{M}_{\mathrm{r}} \\ 1 & & & \\ 2 & \mathrm{CH}_{3} & 4-\mathrm{OCH}_{3} & 438.91 \\ 3 & \mathrm{C}_{2} \mathrm{H}_{5} & 4-\mathrm{OCH}_{3} & 452.94 \\ 4 & \mathrm{C}_{3} \mathrm{H}_{7} & 4-\mathrm{OCH}_{3} & 466.96 \\ 5 & \mathrm{C}_{4} \mathrm{H}_{9} & 4-\mathrm{OCH}_{3} & 480.99 \\ 6 & \mathrm{CH}_{3} & 2-\mathrm{OCH}_{3} & 438.91 \\ & \mathrm{C}_{2} \mathrm{H}_{5} & 2-\mathrm{OCH}_{3} & 452.94\end{array}$

The ultra-short beta-blocking activity of the prepared derivatives was attained by the incorporation of metabolically unstable ester functional group into the connecting chain of the original aryloxypropanolamine structure of the beta-blockers. The substitution on the nitrogen atom of amino group of these drugs differs from that of compounds studied in (Stankovičová, 2011). The hydrogen atom of the amine group is substituted with the phenylethylene group where on the benzene ring is placed in position 2- or in position 4- a methoxy group. Such structural change enhances the lipophilicity of molecule but probably may also affect its stability because the leaving group is bulky. The substitution on secondary nitrogen atom of beta-adrenergic receptor blockers with such group gives the molecule the affinity to both types of adrenergic receptor: alfa and beta such as carvedilol (Graham \& Patric, 2009). Such activity may 
be very important for these new compounds (Graham \& Patric, 2009, Griffith, 2003). These potential drugs may be also indicated at supraventricular tachycardia, at fibrillation, hypertension and at acute myocardial infarction (Mokrý et al., 2003)

Because the hydrolysis is the most frequent reaction in the degradation process of the esters, the stability study of such compounds in different media is very important. The ester functional group is more labile than the ethereal connecting chain. It quickly undergoes hydrolyse, which is the case of shortening of its activity. The studied compounds possess two functional groups, which undergo hydrolysis. At the degradation processes of compounds it is supposed that the first process is hydrolysis of the ester group. Esters are unstable at extremes of $\mathrm{pH}$. The rate of hydrolysis of esters in alkaline solution is greater than their rate of hydrolysis in acidic solution. The rate of ester hydrolysis is affected by the substituents which are present within the structure of the ester. Bulky electron releasing substituents decrease the rate of hydrolysis. The very hydrophobic group slows the hydrolyse in alkaline medium but the rate of hydrolysis is much higher in plasma (Watson, 2011). The hydrolysis of carbamate functional group goes on after its process.

\section{MATERIALS AND METHODS}

\section{Studied compounds}

The studied compounds were synthesised as hydrochloride by authors [4] and are listed in Table 1. All other chemicals and solvents were of analytical reagent grade.

\section{Apparatus}

The Thermostat Memmert WB 10 (Germany), spectrophotometer Spectronic 20 D, Milton Roy (Germany) and spectrophotometer 8452 A DIODE ARRAY Hewlett Packard (USA).

\section{Thin layer chromatography}

The chromatographic separation of degradation products of hydrolysed compounds was carried out on silica gel layer Silufol ${ }^{\circledR}$ UV 254. About $5 \mu$ of examined solution of compound was applied on the plate. An UV light lamp, Camag, was used for detection at wavelength $\lambda=254 \mathrm{~nm}$. Chromatographic system S1: petrolether/diethyl amine $(6.5: 3.5 \mathrm{v} / \mathrm{v})$, chromatographic system $\mathrm{S} 2$ : hexane/acetone/diethyl amine $(5.5: 3.0: 1.5 \mathrm{v} / \mathrm{v} / \mathrm{v})$, and chromatographic system S3: petrol-ether/diethyl amine $(7.0: 3.0 \mathrm{v} / \mathrm{v})$ were saturated for 1 hour in the chromatographic chamber.

\section{Stability tests}

The shortened stability tests were performed by using hydrochloric acid $0.1 \mathrm{~mol} / \mathrm{l}$, sodium hydroxide $0.1 \mathrm{~mol} / \mathrm{l}$, hydrogen peroxide 0.1 per cent solution, buffer solutions of $\mathrm{pH} 7$ and $\mathrm{pH} 8$ at laboratory temperature and at increased temperature $100{ }^{\circ} \mathrm{C}$. To the $0.5 \mathrm{ml}$ of prepared basic solution of compound in methanol $(10 \mathrm{mg} / 10 \mathrm{ml})$ was added 
$0.5 \mathrm{ml}$ of reagent solution, and after 5 minutes of keeping the solution examined in tempered water bath it was investigated chromatographically.

\section{Kinetics of hydrolysis}

The prepared basic solutions of compounds in methanol $(10 \mathrm{mg} / 10 \mathrm{ml})$ were mixed with the reagent solution in ratio $3: 3(\mathrm{v} / \mathrm{v})$ and the solution was heated in thermostat at temperatures $80.0{ }^{\circ} \mathrm{C}$ and $100{ }^{\circ} \mathrm{C}$. The sample was taken in defined time intervals, cooled to laboratory temperature and $0.25 \mathrm{ml}$ was diluted with water to the volume of $10 \mathrm{ml}$; the course of spectrum was registered in the UV region and the values of absorbances at maxima were registered.

\section{Calculations}

The rate constants of hydrolysis are calculated using the kinetic equation of the pseudofirst order from the dependence of $\ln \left[A_{t} /\left(A_{0}\right]=f(t)\right.$ where $A_{0}$ is the value of starting absorbance of the studied compound, and $A_{t}$ is its absorbance in time $t$.

\section{RESULTS AND DISCUSSION}

The degradation of studied compounds is going on as a complex (parallel) reaction. First, the ester group of the side chain of molecule is hydrolysed. The processes take place very quickly. The hydrolysis of the carbamate functional group goes off after its process. The second step of hydrolysis is slow and is the rate determining step. The products of hydrolysis (Figure 1) of these compounds are 2-(4methoxyphenyl)ethylamine (I) or 2-(2-methoxyphenyl)ethylamine (II), propan-1,2-diol (III), and corresponding 4-alkoxycarbonylaminobenzoic acids (IV).<smiles>COc1ccc(CCN)cc1</smiles><smiles>COc1ccccc1CCN</smiles>

II.<smiles>CC(O)CO</smiles>

III.<smiles>CCOC(=O)Nc1ccc(C(=O)O)cc1</smiles>

IV.<smiles>Nc1ccc(C(=O)O)cc1</smiles>

V.

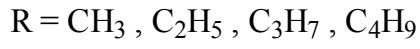

Figure 1. The products of hydrolysis of the studied compounds The final product of hydrolysis is 4-aminobenzoic acid (PABA) (V). 
At alkaline hydrolysis the final products are sodium salts of both acids. The observation of stability of compounds requires suitable analytical methods. Thin layer chromatography and ultraviolet spectrophotometry are suitable for the evaluation of stability study results because they are quickly performable.

For quick observation of the stability of studied compounds we have used the strain tests on them. The tests were performed in hydrochloric acid $0.1 \mathrm{~mol} / 1$, sodium hydroxide $0.1 \mathrm{~mol} / \mathrm{l}$, hydrogen peroxide 0.1 per cent solution, buffer solutions at $\mathrm{pH} 7$ and $\mathrm{pH} \quad 8$ at laboratory temperature and at increased temperature $100{ }^{\circ} \mathrm{C}$. To the prepared basic solution of compound in methanol was added equal volume of reagent solution and after 5 minutes keeping the examined solution in tempered water bath was it investigated chromatographically. For good separation we have used three systems of mobile phases which have been chosen experimentally before tests. The starting values, $R_{f}$, of individual compounds in individual mobile phases are shown in Table 2.

Table 2. The values of retention factors $R_{f}$ of the studied compounds

\begin{tabular}{|c|c|c|}
\hline Compound & Mobile phase & $R_{f}$ \\
\hline 1 & $\mathrm{~S} 1$ & 0.38 \\
2 & $\mathrm{~S} 1$ & 0.41 \\
3 & $\mathrm{~S} 2$ & 0.75 \\
4 & $\mathrm{~S} 2$ & 0.70 \\
5 & $\mathrm{~S} 3$ & 0.28 \\
6 & $\mathrm{~S} 3$ & 0.38 \\
\hline
\end{tabular}

The results of short stability tests are shown in Table 3. The degradation products of all compounds at both temperatures have been found after keeping them in the solution for 5 minutes. There were several spots detected on the chromatographic plates. The stability of compounds 1 and 2 are chromatographically observed in the mobile phase $\mathrm{S} 1$. The values of $R_{f}$ of the original compounds were 0.38 and 0.41 respectively. The $R_{f}$ value of the final product, the 4-aminobenzoic acid, in all mobile phases is 0 . The results in Table 3 show that both compounds are decomposed. Compound 3 was in sodium hydroxide solution, hydrolysed immediately at both temperatures. In hydrochloric acid, hydrogen peroxide and in buffer solution of $\mathrm{pH} 7$ at $20{ }^{\circ} \mathrm{C}$, compound 3 was stabile because no spots of degradation product were found. In buffer solution of $\mathrm{pH} 8$ the degradation started after $5 \mathrm{~min}$ of influence at $20{ }^{\circ} \mathrm{C}$; the two spots are present on the chromatographic plate. The influence of all reagents at $100{ }^{\circ} \mathrm{C}$ caused total degradation of the compound. In the meantime the original compound was not present on the chromatogram. The same results were obtained also with compound 4 . The chromatography of compounds 3 and 4 was performed in mobile phase S2. The chromatographic analysis of stability of compounds 5 and 6 was performed in mobile phase S3. The spots of 4-aminobenzoic acid were found after 5 minutes of hydrolysis in sodium hydroxide $0.1 \mathrm{~mol} / 1$ solutions at $20{ }^{\circ} \mathrm{C}$ as well as at $100{ }^{\circ} \mathrm{C}$. All compounds are degraded more quickly according to chromatography results in sodium hydroxide solution. 
Table 3. Chromatographic study of stability of compounds 1 and 2 (mobile phase S1), compounds 3 and 4 (mobilephase S2), compounds 5 and 6 (mobile phase S3)

\begin{tabular}{|c|c|c|c|c|c|c|c|}
\hline \multirow{2}{*}{$\begin{array}{c}t \\
{\left[{ }^{\circ} \mathbf{C}\right]}\end{array}$} & \multirow{2}{*}{ Solution } & \multicolumn{6}{|c|}{$R f$} \\
\hline & & $\begin{array}{c}\text { Compound } \\
1\end{array}$ & $\begin{array}{c}\text { Compound } \\
2\end{array}$ & $\begin{array}{c}\text { Compound } \\
3\end{array}$ & $\begin{array}{c}\text { Compound } \\
4\end{array}$ & $\begin{array}{c}\text { Compound } \\
5\end{array}$ & $\begin{array}{c}\text { Compound } \\
6\end{array}$ \\
\hline \multirow{5}{*}{20} & $\begin{array}{c}\mathrm{HCl} \\
0.1 \mathrm{~mol} / 1\end{array}$ & 0.46 & 0.35 & 0.75 & 0.68 & 0.22 & 0.26 \\
\hline & $\begin{array}{c}\mathrm{NaOH} \\
0.1 \mathrm{~mol} / \mathrm{l}\end{array}$ & $\begin{array}{l}0.48 \\
0.28\end{array}$ & $\begin{array}{l}0.55 \\
0.38\end{array}$ & 0.20 & 0.24 & 0.0 & 0.06 \\
\hline & $\begin{array}{l}\mathrm{H}_{2} \mathrm{O}_{2} \\
0.1 \%\end{array}$ & 0.41 & 0.44 & 0.74 & 0.64 & 0.20 & $\begin{array}{l}0.07 \\
0.29\end{array}$ \\
\hline & $\mathrm{pH} 7$ & 0.64 & 0.70 & 0.72 & 0.67 & 0.19 & 0.27 \\
\hline & $\mathrm{pH} 8$ & 0.61 & 0.63 & $\begin{array}{l}0.71 \\
0.22\end{array}$ & $\begin{array}{l}0.72 \\
0.30\end{array}$ & 0.20 & 0.29 \\
\hline \multirow{5}{*}{100} & $\begin{array}{c}\mathrm{HCl} \\
0.1 \mathrm{~mol} / 1\end{array}$ & 0.48 & 0.54 & 0.52 & 0.54 & $\begin{array}{l}0.05 \\
0.22\end{array}$ & $\begin{array}{l}0.08 \\
0.26\end{array}$ \\
\hline & $\begin{array}{c}\mathrm{NaOH} \\
0.1 \mathrm{~mol} / 1\end{array}$ & $\begin{array}{l}0.76 \\
0.34\end{array}$ & $\begin{array}{l}0.65 \\
0.47\end{array}$ & 0.22 & 0.35 & 0.0 & 0.0 \\
\hline & $\begin{array}{l}\mathrm{H}_{2} \mathrm{O}_{2} \\
0.1 \%\end{array}$ & 0.42 & 0.46 & $\begin{array}{l}0.54 \\
0.32 \\
0.18\end{array}$ & $\begin{array}{l}0.49 \\
0.23\end{array}$ & $\begin{array}{l}0.03 \\
0.20\end{array}$ & $\begin{array}{l}0.02 \\
0.29\end{array}$ \\
\hline & $\mathrm{pH} 7$ & 0.55 & 0.59 & $\begin{array}{l}0.54 \\
0.31 \\
0.17\end{array}$ & $\begin{array}{l}0.57 \\
0.35 \\
0.23\end{array}$ & $\begin{array}{l}0.03 \\
0.34\end{array}$ & 0.07 \\
\hline & $\mathrm{pH} 8$ & 0.39 & 0.58 & $\begin{array}{l}0.67 \\
0.33 \\
0.19\end{array}$ & $\begin{array}{l}0.61 \\
0.36 \\
0.25\end{array}$ & $\begin{array}{l}0.04 \\
0.38\end{array}$ & $\begin{array}{l}0.04 \\
0.29 \\
0.54\end{array}$ \\
\hline
\end{tabular}

In Table 4 are shown the results of the chromatographically observed course of decomposition of compounds 1 and 2 in buffer solutions of $\mathrm{pH} 7$ and $\mathrm{pH} 8$ at $100{ }^{\circ} \mathrm{C}$ during 2 hours. The mobile phase S1 was used. Two or three spots on chromatogram were detected.

Table 4. The values of rate constants of hydrolysis in $\mathrm{NaOH} c=0.1 \mathrm{~mol} / \mathrm{l}$ at $80.0{ }^{\circ} \mathrm{C}$

\begin{tabular}{|c|c|c|c|}
\hline Compound & $\begin{array}{c}\boldsymbol{k} \times \mathbf{1 0}^{\mathbf{3}} \\
{\left[\mathbf{m i n}^{-1}\right]}\end{array}$ & $\begin{array}{c}t_{1 / 2} \\
{[\mathrm{~h}]}\end{array}$ & $\begin{array}{c}t_{90} \\
{[\mathrm{~h}]}\end{array}$ \\
\hline $\mathbf{1}$ & $1.50 \pm 0.37$ & 7.6 & 1.2 \\
$\mathbf{2}$ & $1.64 \pm 0.12$ & 7.0 & 1.1 \\
$\mathbf{3}$ & $1.67 \pm 0.20$ & 6.9 & 1.05 \\
$\mathbf{4}$ & $2.02 \pm 0.48$ & 5.7 & 0.9 \\
\hline
\end{tabular}

The results of alkaline hydrolysis of compounds $1,2,3$ and 4 at $80{ }^{\circ} \mathrm{C}$ in sodium hydroxide $c=0.1 \mathrm{~mol} / \mathrm{l}$ are shown in Table 5. The rate constants have been determined in the UV region via kinetics of the pseudo-first order. Because the studied compounds possess two functional groups which undergo hydrolysis, by this method it is possible to observe only the apparent rate constants of hydrolysis. 
Table 5. The values of rate constants of hydrolysis at $\mathrm{pH} 7$ and $100.0{ }^{\circ} \mathrm{C}$

\begin{tabular}{|c|c|c|c|}
\hline Compound & $\begin{array}{c}\boldsymbol{k} \times \mathbf{1 0}^{\mathbf{3}} \\
{\left[\mathbf{m i n}^{-1}\right]}\end{array}$ & $\begin{array}{c}t_{1 / 2} \\
{[\mathrm{~h}]}\end{array}$ & $\begin{array}{c}t_{90} \\
{[\mathrm{~h}]}\end{array}$ \\
\hline 1 & $3.66 \pm 1.03$ & 3.1 & 0.48 \\
2 & $3.59 \pm 0.16$ & 3.2 & 0.49 \\
3 & $5.02 \pm 0.33$ & 2.3 & 0.35 \\
4 & $9.04 \pm 2.24$ & 1.3 & 0.20 \\
5 & $3.76 \pm 0.16$ & 3.1 & 0.47 \\
6 & $4.04 \pm 0.51$ & 2.9 & 0.43 \\
\hline
\end{tabular}

The values of rate constants rise with prolongation of the alkyl chain of the carbamate group. Hydrolysis of the carbamate group is the rate determining process in this case. The values of rate constants of hydrolysis at $\mathrm{pH} 7$ and $100.0^{\circ} \mathrm{C}$ are shown in Table 6 . Because of the lower concentration of sodium hydroxide in the buffer, we have used higher temperature for observation of hydrolysis. The values of rate constants of hydrolysis indicate rise of hydrolysis rate with the prolongation of substitution in the carbamate group. The rate of hydrolysis of the studied compounds rises with the rise of temperature.

The course of hydrolysis of compound 5 in hydrochloric acid $0.1 \mathrm{~mol} / 1$ at temperature $100{ }^{\circ} \mathrm{C}$ determined via kinetics of pseudo-first order is depicted in Fig. 2. The value of rate constant is $k=1.77 \times 10^{-3} \pm 0.23 \mathrm{~min}^{-1}$; the half-life is $t_{1 / 2}=6.5 \mathrm{~h}$.

Figure 2. The course of hydrolysis of compound 5 in hydrochloric acid $\mathrm{c}=0.1 \mathrm{~mol} / \mathrm{l}$

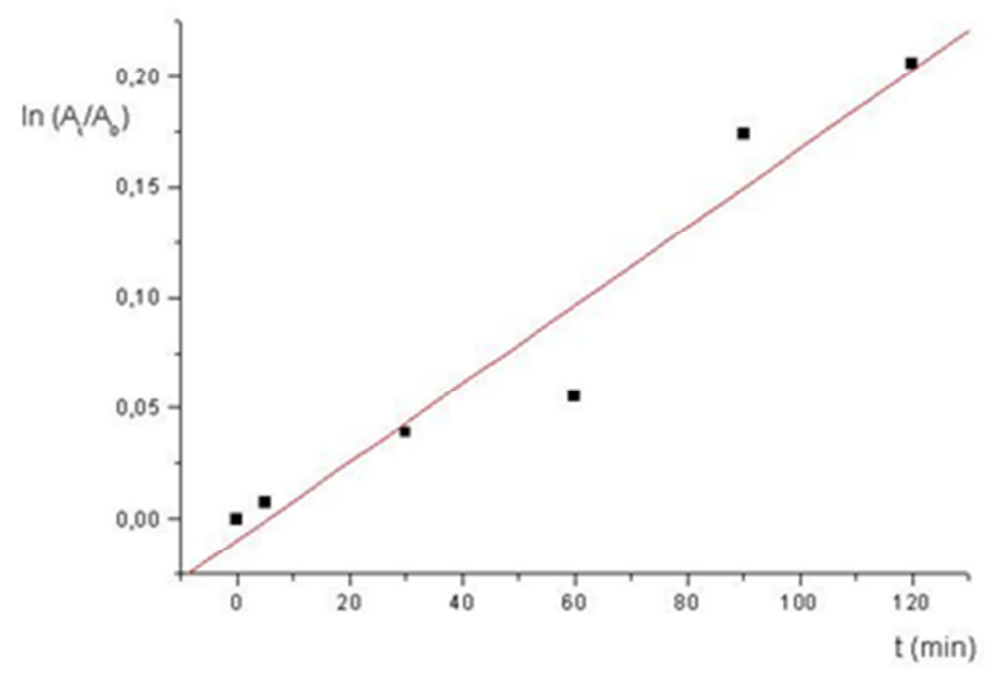




\section{CONCLUSION}

The studied compounds possess two functional groups, which undergo hydrolysis. The TLC analysis provided the 4-aminobenzoic acid as degradation product and two other products: the substituted amine and ester of phenylcarbamic acid. The pseudo-first order rate constants of hydrolysis were determined. The compounds are hydrolysed most quickly in sodium hydroxide $0.1 \mathrm{~mol} / 1$ solution. The most slowly hydrolysed are the compounds in hydrochloric acid $0.1 \mathrm{~mol} / 1$ solutions.

\section{ACKNOWLEDGMENT}

The work was supported by the Grant Agency for Science of the Ministry of Education of the Slovak Republic, grant no.1/0055/11.

\section{REFERENCES}

Jackman PG, Iakovidis D, Nero TL, Anavekar NS, Rezmann-Vitti LA, Louis SNS, Mori M, Drummer OH Louis WJ. Synthesis. $\beta$-adrenoreceptor pharmacology and toxicology of S-(-)-I-(4-(2-ethoxy)phenoxy)-2-hydroxy-3-(2-(3,4dimethoxyphenyl)ethylamino)-propane hydrochloride, a short acting $\beta_{1}$-specific antagonist. Eur J Med Chem 2002, 37:731-741.

Bodor N, Buchwald P. Soft drug design: General principles and recent applications. Med Res 2000, 20:58-101.

Kečkéšová S, Sedlárová E. Review of the ultra-short acting beta-adrenergic blockers. (in Slovak) Farm Obzor 2010, 79:3-13.

Mokrý P, Macháčková Z, Pavlica J, Csöllei J. Synthesis and physicochemical properties of novel arylkarbonyloxyaminopropanol derivatives, Proceedings of 40th Drug Synthesis and Analysis Conference, Brno 2011, Faculty of Pharmacy University of Veterinary and Pharmaceutical Sciences Brno, ISBN 978 - 80 - 7305 - 596-6.

Mokrý P, Zemanová M, Csöllei J, Račanská E, Tumová I. Synthesis and pharmacological evaluation of novel potential ultra-short acting $\beta$-blockers. Pharmazie 2003, 58:18-21.

Stankovičová M, Bezáková Ž, Pavlíková J, Mažeriková J, Kissová M, Mokrý P, Csöllei J. Study of stability of potential beta-adrenolytics, derivatives of the [(arylcarbonyl)oxy]aminopropanol by kinetics of alkaline hydrolysis. Acta Facult Pharm Univ Comenianae. 2011, 58:72-80. 
Graham L, Patrick K. An Introduction to Medicinal Chemistry, Fourth Ed. Oxford University Press, 2009:620.

Griffith RK. Adrenergics and adrenergic blocking agents. In ABRAHAM D. J.: Burger's Medicinal Chemistry and Drug Discovery. Vol 6. Nervous System Agents. 6th ed. New York: John Willey \& sons, 200:1-39.

Watson DG. Pharmaceutical Chemistry. Churchil Livingstone Elsevier. 2011, p. 95.

Registered: September 15, 2012 Accepted: October 25, 2012
Doc. RNDr. Mária Stankovičová, CSc.

Comenius University in Bratislava

Faculty of Pharmacy

Odbojárov 10

83232 Bratislava

Slovak Republic

StankovicM@fpharm.uniba.sk

\title{
HODNOTENIE STABILITY POTENCÁLNYCH BETA-ADRENOLYTÍK V RÔZNYCH ROZTOKOCH CHROMATOGRAFIOU NA TENKEJ VRSTVE A KINETIKOU HYDROLÝZY
}

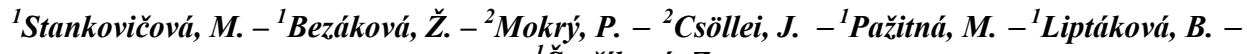 \\ '̌́sevíková, $Z$.

\footnotetext{
${ }^{1}$ Univerzita Komenského v Bratislave Farmaceutická fakulta Katedra farmaceutickej chémie,

${ }^{2}$ Veterinárna a farmaceutická univerzita Brno, Farmaceutická fakulta Ústav chemických liečiv
}

Ciel'om tejto práce je štúdium stability and kinetiky hydrolýzy vybratých látok, derivátov 2hydroxy-3-[2-(4-metoxyfenyl)etylamino]propyl-4-[(alkoxykarbonyl)amino]benzoátov a 2hydroxy-3-[2-(2-metoxyfenyl) etylamino] propyl-4-[(alkoxykarbonyl)amino]benzoátov s potenciálnym ultra-krátkym beta-adrenolytickým účinkom. Študované látky sa odlišujú polohou substituenta na benzénovom kruhu $\mathrm{v}$ bočnom ret’azci, ako aj na aromatickom kruhu $\mathrm{v}$ polohe 4 (metyl- až butyl- karbamát). Na vyhodnotenie stability týchto potenciálnych liečiv sa využili chromatografia na tenkej vrstve a UF spektrofotometria. Štúdie stability látok boli vyhodnotené v kyslom a alkalickom prostredí, $v$ tlmivých roztokoch a pôsobením oxidácie pri izbovej teplote a pri zvýšenej teplote chromatograficky, hodnoty $R_{f}$ počiatočných a rozkladných produktov boli detegované. Spektrofotometriou v UF oblasti bola vyhodnotená kinetika kyslej a alkalickej hydrolýzy v rôznych roztokoch pri teplote $80{ }^{\circ} \mathrm{C}$ a $100^{\circ} \mathrm{C}$. Boli stanovené kinetické parametre ako rýchlostná konštanta $k$, doba polčasu $t_{1 / 2}$ a čas použitel'nosti $t_{90}$.

Acta Fac. Pharm. Univ. Comen. LIX, 2012, (2), p. 54-62. 